\title{
Food waste paradox: antecedents of food disposal in low income households
}

\author{
Gustavo Porpino ${ }^{1}$, Juracy Parente ${ }^{2}$ and Brian Wansink ${ }^{3}$ \\ ${ }^{1}$ Getulio Vargas Foundation (FGV-EAESP) and Embrapa, Brasília, DF, Brazil \\ ${ }^{2}$ Getulio Vargas Foundation (FGV-EAESP), São Paulo, SP, Brazil \\ ${ }^{3}$ Charles H. Dyson School of Applied Economics and Management, Cornell University, Ithaca, New York, USA
}

\section{Keywords}

household food waste, food consumption, low income, Brazilian market.

\section{Correspondence \\ Brian Wansink, Charles H. Dyson School of Applied Economics and Management, Cornell University, Ithaca, New York, USA. \\ E-mail: fblsubmissions@cornell.edu}

doi: $10.1111 /$ ijcs.12207

\begin{abstract}
This article aims to identify antecedents of food waste among lower-middle class families - a paradox, given the financial constraints this population faces. The importance of this research is evident in escalating environmental pressures for better use of our planet's scarce resources. Given that most of the world is low-income, any behavioral change in this population is likely to have a considerable impact. Empirical data were collected from 14 lower-middle income Brazilian households, based on observations, in-depth interviews, photographs and a focus group $(n=6)$. Five major categories of food waste antecedents were identified: (1) excessive purchasing, (2) overpreparation, (3) caring for a pet, (4) avoidance of leftovers and (5) inappropriate food conservation. Several subcategories were also found, including impulse buying, lack of planning and preference for large packages. Surprisingly, findings show that strategies used to save money - such as buying groceries in bulk, monthly shopping trips, preference for supermarkets and cooking from scratch - actually end up generating more food waste. This mitigates the savings made during the purchasing phase.
\end{abstract}

\section{Introduction}

In a world that faces both scarcity of natural resources and extreme poverty, why does household food waste seem to be so prevalent? While more than 2.2 billion people are either near or living in poverty (United Nations Development Programme [UNDP], 2014), almost one third of the food produced worldwide is wasted. This waste equates to $250 \mathrm{~km}^{3}$ of water and 1.4 billion hectares of land use, adding 3.3 billion tons of greenhouse gases to the earth's atmosphere (The Food and Agriculture Organization of the United Nations [FAO], 2013a).

The seventh largest economy in the world (World Bank, 2013) and a major food exporter, Brazil concentrates most of its losses in the immediate post-harvest stage (Soares, 2009), but it also has large amounts of waste at the end of the chain. In fact, Brazil is among the nations that waste more food at the consumer and retail level than is needed to feed those who still face hunger (FAO, 2014), estimated to be 7.2 million (Brazilian Institute of Geography and Statistics [IBGE], 2014). Why is so much food wasted among the lower-middle class in Brazil?

Considering its yearly per capita income of US\$11,000 (World Bank, 2013), Brazil is considered a high-middle income country. Nevertheless, due to its high-income inequality, most Brazilian households are classified as low-income families, which make it a feasible representation of the world. This study proposes that even lower-middle class families may frequently waste food due to behavioral and cultural aspects, a topic scarcely researched in marketing literature.

According to FAO (2014), Latin American consumers waste on average $28 \%$ of their food, but consistent data is missing to provide a precise estimate focused on Brazil. Considering the whole supply chain, Brazil loses an estimated of $35 \%$ of its agricultural production (Carvalho, 2009).

Household food waste has been considered characteristic of high-income nations (Stuart, 2009; Gustavsson et al., 2011; Beretta et al., 2013) and families with less purchasing power would be expected to be more careful about how they spend their money on food. Reports from the FAO (2013b,c), the Institution of Mechanical Engineers (Aggidis et al., 2013) and the Barilla Center for Food and Nutrition (Buchner et al., 2012) also tend to relate affluence with food disposal. We assume that, in order to understand the paradox of food waste among low-income families, a broad analysis of other variables besides household income is mandatory.

Considering the lack of empirical studies aimed at identifying antecedents of waste at the family level, this paper investigates the household food waste phenomenon and aims to identify antecedents of food waste in the final stage of the supply chain. Households serve as the unit of analysis. This study identifies which behavioral and cultural factors contribute to food waste 
among low-income consumers. Low income does not refer to families living below the poverty line, but rather the lowermiddle class Brazilian families, which represent $1 / 3$ of the population.

The following section presents literature pertinent to our work, with an emphasis on culture and waste in Brazil. We then discuss our research methodology. The subsequent section is devoted to the presentation and interpretation of the empirical data. We conclude by summarizing the paper's findings, and showing the implications for reducing household waste.

\section{Literature review}

The literature seems to lack a clear understanding of the antecedents of household food waste. There are few studies on the topic of food waste and its association with consumer behavior (Stefan et al., 2013). Evans et al. (2013) claim that the phenomenon remains neglected, and the research content and style have failed to present a broader view of the problem. Academic studies also lack a deeper understanding of how waste may be a consequence of the ways in which domestic food practices are socially organized (Evans, 2011). Although Koivupuro et al. (2012), Stefan et al. (2013) and Williams et al. (2012) have addressed the issue, a study including a cultural perspective should contribute to an improved understanding of the phenomenon.

\section{Food waste and loss}

There is no single definition for 'food waste'. While Gustavsson et al. (2011) define it as the non-use of food in the stages of distribution and consumption, Leal Filho and Kovaleva (2015) cite that it might arise at any point in the food supply chain as a result of innapropriate behavior of producers, retailers or consumers, as well as lack of technological inputs.

Drawing from Gustavsson et al. (2011) and Ganglbauer et al. (2013, p. 11), we define food waste as unintended losses of food produced for human consumption occurred in the distribution and consumption stages of the food supply chain due to 'multiple moments of consumption dispersed in space and time across other integrated practices such as shopping and cooking', which are themselves embedded in contextual and cultural factors. Despite of being unintended, most food waste is avoidable. In the United States, for instance, an estimated of $64 \%$ of household food waste is avoidable (O'Donnell, 2014).

As illustrated in Fig. 1, 'food loss' is the waste in the earlier stages of the food supply chain. This term has also been used broadly to represent the amount of edible food, postharvest, that is available for human consumption but is not consumed for any reason (Buzby, 2014). In this sense, food waste is part of food loss.

In high-income nations, the largest contribution to food waste comes from the consumer (Graham-Howe et al., 2014). In low-income countries, however, losses early in the food chain are more common, due to low technological support in the management of crops, lack of structure for storing produce and inadequate infrastructure for the distribution of crops (Aggidis et al., 2013). In the first stage, the losses stem from improper harvest (Gustavsson et al., 2011), among other causes, such as pests, diseases and natural disasters.

In relation to the last stage, Stuart (2009) posits that in developed nations, consumers tend to waste food because they can afford to buy excess food, among other reasons. Gustavsson et al. (2011) claim that in low-income countries, consumption-stage waste is minimal due to the limited purchasing power and procurement of food in small, daily quantities.

\section{Antecedents of waste}

While an estimated $46 \%$ of waste comes from the stages of processing, distribution and consumption of the food supply chain (Pressinott, 2013), relatively little is known about the drivers of waste within households, especially in a developing world perspective. Most efforts to understand household food waste come from the United Kingdom. Among what it is known about food waste in families, Graham-Rowe et al. (2014) identified four core barriers to minimizing it as: (1) a 'good' provider identity; (2) minimizing inconvenience; (3) lack of priority; and (4) exemption from responsibility.

Table 1 presents a list of studies that have identified antecedents of household food waste. Recent literature discusses the relationship between packaging and waste (Williams et al., 2012), the influence of labeling on waste (Milne, 2013), and the topic of domestic food practices (Evans, 2011). At the consumer level, planning, shopping and stockpiling routines are important predictors of waste (Wansink and Deshpandé, 1994; Chandon and Wansink, 2002; Stefan et al., 2013). Also mentioned in studies are other behavioral characteristics related to consumption culture, such as over-preparation and excessive purchasing. One stream of research suggests as much as $11 \%$ of purchased food products are wasted by not even being opened (Wansink, 2001). The most common reason for this is because people purchase them for special occasions that never happen or because they forget about them until they are too old to use (Wansink et al., 2000).

When commenting on shopping as an integrated practice, Ganglbauer et al. (2013, p. 19) explain that some households go shopping in the context of other dispersed practices such as

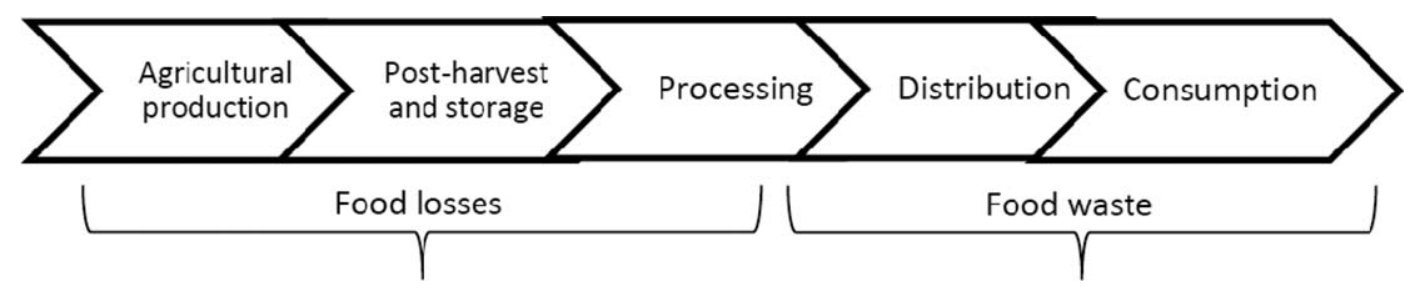

Figure 1 The food chain. Source: Elaborated by the authors, based on Gustavsson et al. (2011) and Parfitt et al. (2010). 
Table 1 Antecedents identified in the literature

\begin{tabular}{|c|c|c|}
\hline Variable & Author & Itinerary phase (refer to Fig. 2) \\
\hline $\begin{array}{l}\text { Socio-demographical factors (single } \\
\text { household type, woman responsible for } \\
\text { grocery shopping) }\end{array}$ & Koivupuro et al. (2012) & $\begin{array}{l}\text { Planning and negotiating the } \\
\text { purchase }\end{array}$ \\
\hline $\begin{array}{l}\text { No or incorrect purchase and meals } \\
\text { planning }\end{array}$ & $\begin{array}{l}\text { Schneider (2008), Parfitt et al. (2010), Evans (2011), } \\
\text { Ganglbauer et al. (2013), Stefan et al. (2013) }\end{array}$ & \\
\hline Children in the family & Terpstra et al. (2005) & \\
\hline Poor home economics skills & Cox and Downing (2007) & \\
\hline In-store behavior (impulse buying) & Parfitt et al. (2010) & Buying food \\
\hline Excessive purchase & $\begin{array}{l}\text { Harrison et al. (1975), Cox and Downing (2007), Koivupuro } \\
\text { et al. (2012), Beretta et al. (2013), Ganglbauer et al. } \\
\text { (2013), Graham-Howe (2013), Stefan et al. (2013) }\end{array}$ & \\
\hline Retail offers and promotions & $\begin{array}{l}\text { Cox \& Downing (2007), Schneider (2008), Godfray et al. } \\
\text { (2010) }\end{array}$ & \\
\hline Buying food in large packages & $\begin{array}{l}\text { Ganglbauer et al. (2013), Koivupuro et al. (2012), Williams } \\
\text { et al. (2012) }\end{array}$ & \\
\hline $\begin{array}{l}\text { Lack of knowledge about food storage } \\
\text { and handling }\end{array}$ & $\begin{array}{l}\text { Parfitt et al. (2010), Terpstra et al. (2005), Koivupuro et al. } \\
\text { (2012), Barilla (2012), Williams et al. (2012), Plumb and } \\
\text { Downing (2013) }\end{array}$ & Stocking food at home \\
\hline $\begin{array}{l}\text { Long storage time (e.g. exceed expiration } \\
\text { date or spoiled leftovers) }\end{array}$ & $\begin{array}{l}\text { Kantor et al. (1997), Quested and Jonhson (2009), Williams } \\
\text { et al. (2012) }\end{array}$ & \\
\hline Wrong interpretation of food label & Parfitt et al. (2010), Milne (2013) & \\
\hline $\begin{array}{l}\text { Food provisioning routine (domestic food } \\
\text { practices) }\end{array}$ & Evans (2011), Stefan et al. (2013) & Preparing food \\
\hline Overcooking & $\begin{array}{l}\text { Kantor et al. (1997), Blair and Sobal (2006), Cox and Downing } \\
\text { (2007), Quested and Johnson (2009), Evans (2012), } \\
\text { Gustavsson et al. (2011), Koivupuro et al. (2012), Williams } \\
\text { et al. (2012), Beretta et al. (2013), Graham-Howe (2013) }\end{array}$ & \\
\hline Good mother identity & Stuart (2009), Graham-Howe et al. (2014) & \\
\hline Dietary transition (more diversified diet) & Parfitt et al. (2010) & \\
\hline Low preference losses (e.g. bread crusts) & Beretta et al. (2013) & \\
\hline High sensitivity to food hygiene & Cox and Downing (2007) & Storage of prepared food \\
\hline
\end{tabular}

Source: elaborated by the authors. Third column links literature with itinerary elaborated from empirical data.

'caring for the family', 'having a social life' and 'living on a tight budget'. The latter, for instance, leads consumers to choose larger packages perceived as less expensive. However, this also increases the likelihood that they would later throw away the unused excess.

In addition to external antecedents of waste, household stockpiling can generate overuse and waste (Wansink and Deshpandé, 1994). Waste can also be increased by the overpreparation of these stockpiled foods (Chandon and Wansink, 2002), or by the over-serving that can occur because of large serving bowls or plates (Wansink and van Ittersum, 2014; Wansink et al., 2014).

It is known that income is positively related to general waste generation (Palatnik et al., 2014), but the literature seems to lack a clear understanding of the relationship between income and food waste. While Gustavsson et al. (2011) state that poverty and limited household income make it unacceptable to waste food and Stefan et al. (2013) found that higher household income leads to more waste, Cox and Dowling (2007) found that low-income families tend to waste more food.

In a study conducted by Quested and Johnson (2009) with self-reports (diary research) of 300 participants in the United
Kingdom, differences in the amount of food waste between socioeconomic classes were minimal. Williams et al. (2012) also found no correlation between household income and food waste in an exploratory study conducted with 61 Swedish households. Moreover, in a survey of 47 households in Gaborone (Botswana), Bolaane and Ali (2004) found that the rate of waste generation (measured as in weight units) was not directly related to household income.

\section{Culture and waste}

In relation to food, Brazil might be described as the land of abundance and diversity. Brazilians celebrate food when it is satisfying and filling, exalting its plenitude (Fajans, 2012). Plentiful and mixed food is a cultural characteristic of Brazil, described by DaMatta (1984) as one of the most important traits in transforming the act of eating into a Brazilian gesture.

The Brazilian cuisine does not favor separate dishes, such as in China or Japan, or the combination of separate dishes that are strong and discontinuous, as in France and England, 'but, rather, the possibility of establishing, also through food, gradations and hierarchies, allowing choices between a food that is 
central and its peripheral adjuncts or ingredients that serve to join and mix' (DaMatta, 1984, p. 64).

These aspects highlighted by DaMatta (1984) bring to mind the term mistura (mixture), a popular word used in Brazil's Southeast to describe the complement for rice and beans, which are usually the staple food. The mistura usually is beef or chicken. Given this hierarchy and the necessity of including up to three side dishes in a typical lunch, it seems that meal planning is essential in avoiding a high amount of leftovers, which might in turn contribute to food waste.

The importance of abundance of food on the table has been prevalent since the colonial period. Even in the face of difficulties such as monoculture, environmental conditions unfavorable for agricultural cultivation, and shortcomings in transportation and preservation of food, there was 'the ostentation of hospitality and abundance' (Freyre, 2002, p.108). Families tried to ascertain that there was plenty on the table, especially to guests, but access to food on a daily basis was difficult.

The relationship between excess food and receptiveness is described by Cascudo (1968) as a habit of the colonial period, a trace of Portuguese culture absorbed by Brazil. 'They served without consulting. Brought the full plate and were supplying it relentlessly beyond the repletion [.] the food piled up confusedly, in front of the guest as a praise for the host's abundance' (Cascudo, 1968, p. 328). For the author, the act of not offering before serving is a symbolic participation of the host family.

In modern times, Brazil has left its status of food importer, when food access was still far from being cheap and consumers faced difficulties in finding certain food products, to become a large agricultural producer. Given the current production surplus, families nowadays have easier access to food products.

As a cultural phenomenon, food is still a central issue in the structuring of identity, as it was in European settlers' descriptions of Brazil. Considerations about eating habits were present from Brazil's first moments of contact with Europeans (Rial, 2005, p. 88). Be it in the letter of Caminha, in 1500 , when the first Portuguese navigators 'discovered' Brazil, or in later writings, the emphasis is on praising the healthiness of food. There is no record of references to food waste.

Brazilian cooking and eating habits were formed from the cultural mosaic of native Indians, the Africans and the Portuguese. Such miscegenation is intrinsic to the process of colonization. By this hybridization, the Portuguese colonizers mitigated climate adversity, giving rise to a more adaptable mestizo population as well as a culture with European, African and native Indian elements (Freyre, 2002).

\section{Methodology}

This qualitative exploratory study explores the consumer decision process (selection, consumption, and disposal of food) based on the itinerary method (Desjeux, 2006; Desjeux et al., 2014), not only because it allows for a distinct perspective from most studies, but also because it permits observation of the phenomenon from a cultural angle. By doing so, we address Koivupuro et al.'s (2012) call for more qualitative studies on the phenomenon.

The itinerary method prioritizes data collection in the context of real life, where practices occur. As Desjeux (2006) suggests, the itinerary itself should cover the seven main stages related to the acquisition of a good or service: (1) the decision at the household, (2) the shopping trip, (3) the purchase moment, (4) organizing purchases at home, (5) the preparation for use, (6) the consumption itself and (7) the disposal. Thus, the in-home interviews covered the entire consumer decision process related to food. The analysis was complemented by in situ observations and photographic records (Appendix), an important tool in the method because they demonstrate the consumption process context (Desjeux et al., 2014).

The initial phase of data collection involved 14 lower-middle class families (Table 2) from two distinct suburbs of a municipality in the eastern metropolitan area of São Paulo.

Table 2 Interviewees' profile

\begin{tabular}{|c|c|c|c|c|c|}
\hline Informant $^{a}$ & Role (food related) & Age & Family type & Household size & Occupation \\
\hline Jenifer & Organizes/prepares & 42 & Couple with daughter and granddaughter & 4 & Seamstress \\
\hline Helen & Buys/Organizes/prepares & 65 & Couple & 2 & Pensioner \\
\hline Karin & Organizes/prepares & 45 & Couple with two kids & 4 & Small Farmer \\
\hline Jessica & Organizes/prepares & 54 & Couple and daughter & 3 & Housewife \\
\hline Naomi & Buys/organizes/prepares & 26 & Couple with one kid & 3 & Housewife \\
\hline Sandra & Buys/organizes/prepares & 52 & Mother with son & 2 & $\begin{array}{l}\text { Local government } \\
\text { employee }\end{array}$ \\
\hline Marianne & Buys/organizes/prepares & 57 & Couple with son & 3 & Housewife \\
\hline Samantha & Buys/organizes/prepares & 36 & Couple with 5 kids & 7 & Housewife \\
\hline Grace (daughter) & Buys/organizes/prepares & 32 & $\begin{array}{l}\text { Mother with five sons, daughter and } \\
\text { two grandsons }\end{array}$ & 9 & Nursing assistant \\
\hline Emily & Buys/organizes/prepares & 47 & Couple with two daughters & 4 & $\begin{array}{l}\text { Local government } \\
\text { employee }\end{array}$ \\
\hline Elizabeth & Buys/organizes/prepares & 67 & Couple & 2 & Retired \\
\hline Anna & Buys/organizes/prepares & 63 & Couple with daughter & 3 & Housewife \\
\hline Jasmine & Buys/organizes/prepares & 63 & Mother with two sons and granddaughter & 4 & Housewife \\
\hline Victoria & Buys/organizes/prepares & 34 & Couple with three kids & 5 & Small retailer \\
\hline
\end{tabular}

Source: empirical data gathered by the authors.

aAll informants' names are pseudonyms. 
Convenience sampling was used. Apart from the estimated lower-middle income, the eligibility criteria included having primary responsibility for food related decisions, and living in a household with at least one relative.

This study was approved by an Institutional Review Board. Mothers gave consent to be interviewed, and participant confidentiality was ensured. Families were not asked about their income, but given the location, and occupation of the head of the family, their income was estimated to be representative of the Brazilian lower-middle class (per capita household income of around US\$250 per month).

The interaction started with an informal conversation about food consumption. Respondents were told that the purpose was to research food consumption, but food waste was not mentioned. When the interviewees brought up the topic of food disposal, they were encouraged to talk more freely about it. A more structured, in-depth interview followed the initial talk. Interviews were transcribed, and content analysis was used to interpret the data gathered. As a way to explore food consumption within households, families were also observed in the process of preparation, consumption and disposal of food. To complement the analysis, we took photos of the environments used to store food (cabinets, fridge and pantry). We also took photos of the environments used to prepare, consume and throw away food. Images are important in distinguishing what consumers say they do from what they actually do.

The researcher remained in the houses for 2 hours on average. However, in three families the amount of time spent was longer (up to 4 hours) in order to follow the preparation and serving of lunch (the main meal in Brazil) over the weekend. Five families were visited twice, one visit in the beginning of the month (when they initially bought their food supply) and another in the third week of the month. These five families had children, and the mother was identified as the nutritional gatekeeper.

To assure that saturation was achieved, a focus group with projective techniques was conducted with six mothers to observe data redundancy. Redundancy was observed after the 14th family was visited and interviewed, and content analysis from the focus group indicated that the core categories were saturated. Data redundancy indicates the point of diminishing returns, or when nothing new is being added (Bowen, 2008). There is no way of knowing beforehand the size of the sample for an inductive study (Stern, 2007). The sample needs to be representative, 'but it's unnecessary to collect huge amounts of data' (Stern, 2007, p.117).

The preference for this approach instead of self-reports of food waste is due to the fact that traditional surveys of food waste have proved to be inefficient, an aspect that justifies the qualitative study. Consumers tend to minimize the amount wasted on assessments of their habits (Stuart, 2009), hence the need to compare what consumers say with in situ observations.

\section{Results}

As presented in Fig. 2, the last four stages of the food itinerary are associated with waste: stocking; preparing; consuming; and storing of prepared food. Empirical evidences show that drivers of food waste in the lower-middle income context include: (1) stocking too much food; (2) over-preparing or not cooking it

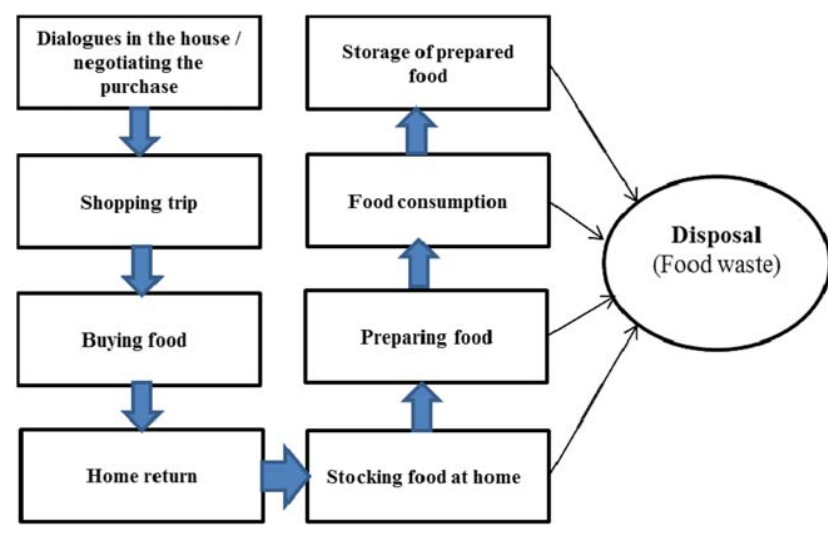

Figure 2 Itinerary for food waste at households. Source: Elaborated by the authors based on empirical data. [Color figure can be viewed in the online issue, which is available at wileyonlinelibrary.com.]

properly (e.g. burning food); (3) leaving food on dishes after meals or not willing to consume leftovers and (4) decaying of prepared food after long or inappropriate storage. These findings challenge the notion that food waste is a prevalent issue only in higher-income families.

The earlier step in this chain linked to food waste, categorized as 'stocking food at home', relates both to excessive purchasing and the inability to manage the food stocked at home. The preference for purchasing large packages contributes to excessive purchasing, and it is justified by families due to the reduced relative price when rice, for instance, is purchased in $5 \mathrm{~kg}$ instead of $1 \mathrm{~kg}$ packages.

Similarly, the option to go to warehouse markets for bulk buying and the preference for large and economy packages seems to underpin over-preparing, which in turn tends to generate more food waste. It can be supposed, therefore, that food waste nullifies the efforts to save financial resources at the time of purchase.

Families reported that some foods were not consumed because they were bought in abundance and past their expiration dates, or because they had forgotten to prepare it. These products are usually the ones more prone to be bought on impulse, such as powder for preparing gelatin, cake mix, sauces and canned food. Evidences of such behavior were also identified in observations (home-tours) and photos taken.

Sometimes I' $m$ in the supermarket and I remember to buy something that I need, but often I also buy useless food stuff, because as you know, woman is like this, I mean when it is on sale, for example, we buy without the real need for it [Sandra, 52]

Despite income constraints, the families studied tended not to plan grocery shopping and in several cases the amount of food they purchased seemed to be greater than needed. Lack of planning and excessive purchasing are among the categories identified, as presented in Table 3. Only two of the 14 families studied prepare shopping lists.

I go to the supermarket once a month with my husband, and we know in our minds what is missing, then we dont prepare a shopping list [Samantha, 36] 
Table 3 Categories and subcategories identified in discourse

\begin{tabular}{ll}
\hline Categories & Subcategories \\
\hline Excessive purchase & Impulse buying \\
& Unplanned purchase \\
& Large package preference \\
& Promotion \\
& Brand loyalty \\
& Taste for tradition \\
& Hospitality \\
Over-preparation & Inability to plan meals \\
& Food seen as wealth \\
& Taste for abundance \\
& Good mother identity \\
Caring for a pet & Sense of caring \\
Avoidance of leftovers & Waste justification \\
& Prejudice against leftovers \\
Food conservation malpractices & Freshness preference \\
& Prepared food not stored in fridge \\
& Inappropriate storage in fridge \\
\hline
\end{tabular}

Source: elaborated by the authors from the data gathered.

It was also interesting to note that some families avoided buying food products on sale, due to the belief that good products are not cheap, as well as the preference for consistently purchasing the same brands. The perception that lower food price is related to low quality occurs when the product on sale is not a leading brand.

He [spouse] always thinks that food products with higher prices is the best option, then he doesńt like sales and we always get the same brands of rice, coffee and so on [Jennifer, 42]

As stated below, brand loyalty is a pervasive tendency. Rice I like to buy 'Prato Fino' or 'Camil', beans is 'Caldo Nobre' and coffee 'Melitta'. I used to buy coffee 'Pilão', but I don't think it is good anymore. And beef has brands now as well, right? I like the one Toni Ramos (Soap Opera actor) advertises on TV [Marianne, 57]

On the other hand, empirical data points to the propensity to buy products seen as great brands in abundance, particularly when they are offered in promotions.

When we see 'buy two, get three' type of promotion, we end up buying, even if we have the product already at home [Jessica, 54]

For instance, in one of the houses visited, occupied by one couple [Helen, 65, informant], we observed a food inventory of $13 \mathrm{~kg}$ of beans, $13 \mathrm{~kg}$ of sugar, $14 \mathrm{~kg}$ of rice, $5 \mathrm{~kg}$ of cornmeal, $4 \mathrm{~kg}$ of salt and eight bottles (900 ml each) of soybean oil and several perishable food products stocked in the fridge. This taste for abundance was prevalent both at the stock and even more related to over-preparation.

We noticed a strong contradiction in how families dealt with food waste. Despite being a widespread practice, there is a strong sense that throwing food away is inappropriate behavior. During the interviews and observation process, mothers were quite embarrassed in admitting the existence of food waste. When food disposal was mentioned, as shown in the following speech, participants usually tried to justify it to avoid feeling shame.
I don't like to throw food away, but sometimes it happens. Like rice... it's more rice or beef, because sometimes we prepare a great quantity. And fruits as well, because it spoils, but I don't buy much fruit, because my son doesn't eat it [Sandra, 52]

Families who have pets or raise chickens usually buy animal food to feed them. However, they also claim that leftovers are used to feed the animals. In the investigated sample, leftovers given to pets are not seen as waste. Families that own dogs, such as Marianne's, tend to waste rice and beans. The following speech also shows a contradictory discourse. After stating that food is not thrown away, the housewife admits that they give the leftovers to the dog even though they continue to buy dog food.

I don't waste food, this rice in the pan is old already, but it goes for the dog. It is not eating dog food, but we buy it [Helen, 65]

Another example of the relationship between the presence of animals and food disposal can be seen in raising chickens.

I prepare food before lunch, but in a big enough quantity to have the remainders for dinner. It remains in the pans (off the fridge), then if after dinner is still food left, we give to the chickens [Karin, 45]

The discarding of unconsumed food after cooking is also due to preparation problems such as burning the food. It can also be due to the housewife waiting on someone who does not show up to lunch, as quoted below. This exemplifies the good mother identity.

Sometimes there is plenty of food left, because I expect my sons to come, then if they don't come, I end up giving to the dog [Marianne, 57]

The so-called good mother identity (Stuart, 2009) is characterized by the desire to provide plenty of food and it is related to the role of the matriarch. This can generate more waste and has been also reported to be a barrier to minimizing food waste in a study conducted in UK households (Graham-Howe et al., 2014).

Caring for the family was also found in the following quote, which also relates to the good mother identity.

My son ate plenty of greenery today at lunch, then I prepared pasta for him to dinner, but he didnt eat. It ended up going to the poultry [Karin, 45]

Food is also wasted after consumption due to over serving. Some families even show an unwillingness to reheat food that was prepared for a previous meal. This aspect also shows a lack of planning for meals.

If there is leftover after lunch, I don't use it. I throw away. We have a canister to dispose food, and my brother-in-law

takes the discarded food to give to the poultry [Samantha, 36]

Finally, mainly due to over-preparation, food remains after the meals. Even when stored in the fridge later, it might still be wasted. For instance, most families prepare rice on a daily basis, and if the rice prepared for lunch is not consumed entirely at dinner, it ends up being thrown away or serves as pet food. In some families, we identified a 'maturation time' that diminished the guilt that occurred when an edible food was discarded, an aspect also noted by Evans (2012). In such situation, food remains in the fridge or elsewhere even after recognition of the fact that it is not edible anymore and that it will be rejected later on.

Even in small families, such as Helen's, the one in charge of cooking tends to prepare an entire pan of rice on a daily basis. 
This taste for abundance was related to an aversion to being identified as poor. Mothers recurrently stated that it is better to make more - rather than not enough - food.

Beans are usually prepared three times a week, and meals are complemented by beef or chicken, which is prepared almost daily. Even in households with three members, bread seems to be bought in bulk (up to 12 per day), which generates waste. In Marianne's interview, waste, aside from over-preparation, also seems related to the usual excessive purchasing of bread, which in fact was observed in several families.

I like to prepare a great quantity. Then, usually there is rice left, and bread as well always remains a bunch uneaten

[Marianne, 57]

When commenting on food preparation, mothers tend to also justify over-preparing due to practicality. They show a preference for preparing a greater amount of food at once to save time. Hospitality seems to be another characteristic linked to over-preparation, as does the willingness to be a good provider. This results in a tendency to serve kids larger portions of food than they can eat.

Ample storage is also a matter of practicality and time saving. The families studied tended to prefer buying food at supermarkets once a month. The shopping trip occurs a few days after receiving wages, and it usually involves people outside of the household. It is common for a family member, such as a son that lives close by, to offer transportation to his parents (who do not own a car) to and from the supermarket.

Another prevalent trait in the sample studied is the lack of knowledge about adequate food storage. In almost every family, produce and beef is improperly stored in the fridge, and prepared food remains for a period of up to 12 hours without refrigeration. In some cases, it was observed that rice and beans were kept in pans over the cooktop for 24 hours.

Table 3, below, summarizes the major categories and subcategories of antecedents of household food waste.

\section{General discussion}

All 14 families studied live in houses with small yards. They still adopt more traditional life styles, where women play a role as typical 'housewives', being in charge of most domestic chores, including cooking. We also observed that all these mothers have the habit of cooking from scratch, which can lead to over-preparation and therefore to more waste.

Based on our interviews and observations, we believe that cooking from scratch is connected to the willingness to be perceived as a good provider and to show hospitality for community members and relatives. Hospitality, a category that emerged in our study, is embedded in the practice of 'having a social life', identified by Ganglbauer et al. (2013). Therefore, intentions are positive and the negative outcome (food waste) can be avoided if mothers improve planning skills (meals and grocery shopping) and understand that when food is wasted they are losing money.

\section{An integrated framework of household food waste}

Figure 3 proposes an integrated framework to better depict the phenomenon of food waste. This model provides an improved understanding of this phenomenon by articulating the two major sets of dimensions related to household food waste phenomenon - the different domestic phases where household food waste takes place and the major antecedents of that waste. The model can serve as a reference for future empirical studies to establish more specific relationships between the dependent variable waste and its antecedents.

Excessive purchasing, over-preparation and unwillingness to consume leftovers were some of the main antecedents of food waste we identified. They are embedded in cultural practices such as hospitality, the good mother identity, taste for abundance, and food seen as wealth. The contradiction of food waste in a low-income context can be explained by the influence of these cultural aspects.

Interestingly, a key finding not explored in the literature is that pet ownership serves as a justification for food waste. Families studied do not perceive that they are wasting edible food when the leftovers are given to dogs or poultry. In relation to composting, none of the 14 families have a composter bin.

On the other hand, the antecedent of inappropriate food conservation is more related to lack of knowledge about food storage. Given this circumstance, campaigns about how to preserve and store food might encourage greater practice of food conservation in households. Consumers should also be encouraged to realize that by using appropriate containers instead of, for instance, empty margarine pots to store beef in the fridge, they will end up saving financial resources by wasting less.

The study presents empirical evidence of these five antecedents in a low-income context, which fulfills our objective and contributes to previous consumer behavior studies on food waste. Overall, food waste is a real problem in lower-middle class families, and urgent action is needed in terms of educating them to make smarter purchases, to store food appropriately, and to adopt a healthier diet.

Given that most of the world is low income, a small change in the behavior of this segment has a considerable impact on society as a whole. Some strategies adopted by lower-middle class families to save money at the beginning of the chain from the shopping trip until the preparation of food - are nullified by the food wasted at the end of the chain. Bulk buying (to pay a relatively reduced price) and the preparation of food in abundance, justified to save cooking time but also related to food seen as wealth, generate more food waste.

\section{Limitations and future research}

This qualitative exploratory study's intention was to better understand the phenomenon of food waste but not to generalize the findings. That being said, the sample might not be representative of the Brazilian lower-middle class. Even though the study was conducted in only two suburbs of a municipality in São Paulo's eastern metropolitan area, we believe that the findings would hold in other Brazilian regions.

There is also a need to classify families more precisely in terms of income. Data from the census conducted in 2010 (UNDP, 2013) estimate that the per capita monthly income in the area studied is R $\$ 520$ (US\$200). Compared with developed nations, this is representative of the low-income segment, but within Brazil it is classified as lower-middle class, the term used to refer to the sample in this article. 


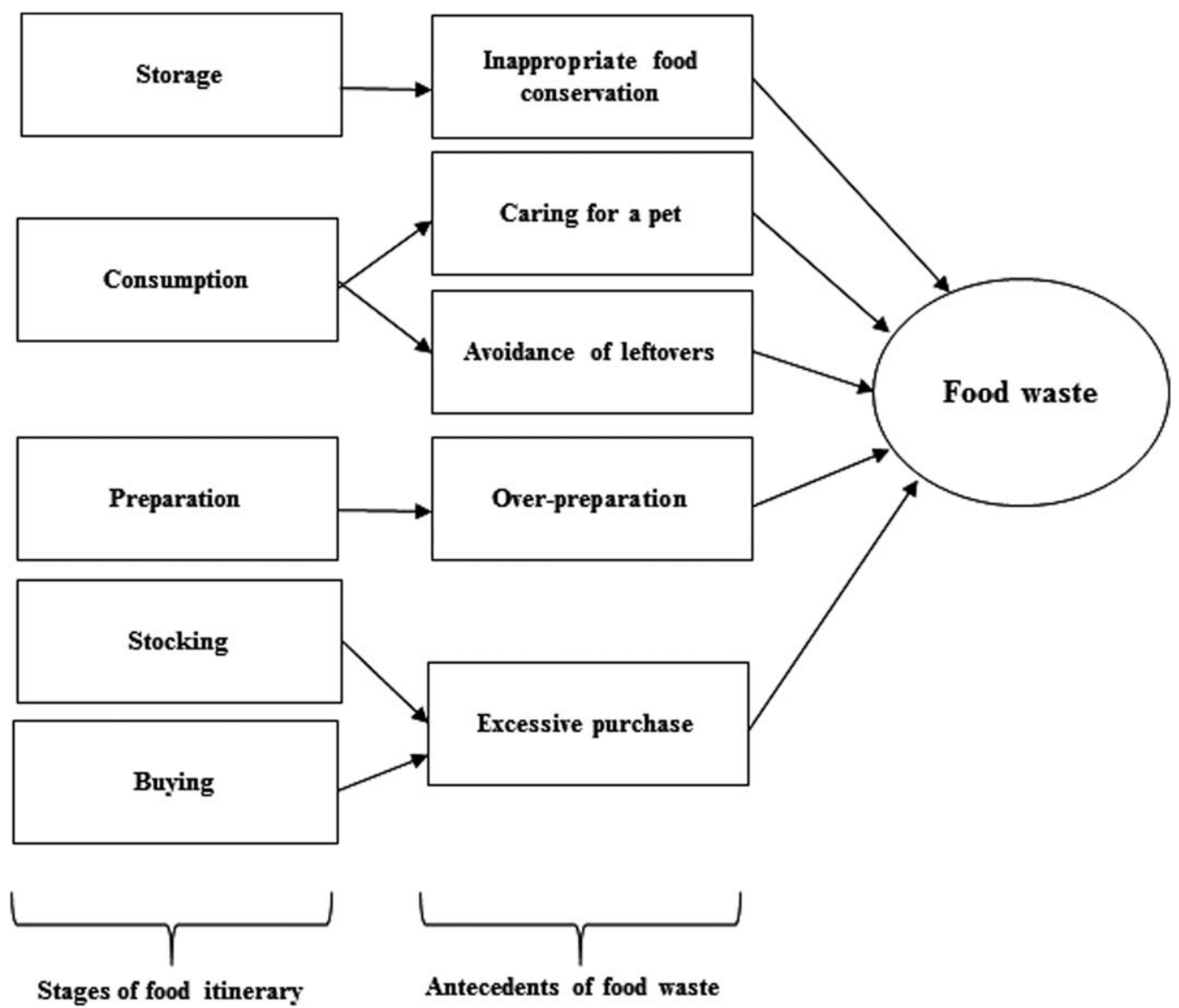

Figure 3 Integrated model of household food waste: itinerary stages and antecedents. Source: elaborated by the authors based on empirical data.

This study does not imply that food waste is greater in low income families than in the more affluent ones, but given the financial resources constraints the poorer face, it is inferred that they would have a better life quality if they changed their food purchasing, cooking, consumption, and disposing behavior. We also do not intend to blame families for the food they waste. In fact, it was found that even positive intentions (e.g. hospitality) might be a driver for food waste.

In order to gain a deeper understanding of the household food waste phenomenon, further investigations could replicate this study in different contexts: regions, countries and income segments. The proposed 'Integrated model of household food waste' can serve as a reference for future empirical studies to establish more specific relationships between the dependent variable waste and its antecedents. Because most antecedents identified are related to cultural aspects, it will require long-term immersion in the field to get a deeper understanding of the phenomenon. That being said, more ethnographic oriented methods can be applied to enrich the findings. Mixed-method approaches could also shed light on this problem by focusing on specific variables (e.g. leftover avoidance).

\section{Implications for practitioners and public policies}

Supermarket chains, particularly ones located in low-income areas, could strengthen their relationship with consumers by offering educational sessions not only on cooking tips, but also on food storage techniques. Given the perceived lack of access to appropriate containers (e.g. glass storage containers) and the preference mothers show for shopping in supermarkets, it could be a win-win solution in which retailers would sell more products that store prepared food and consumers would benefit from wasting less.

Findings indicate that the lower-income segment would benefit from better meal planning and appropriate food storage. National food stamp programs, such as the Bolsa Família in Brazil, and the Supplemental Nutrition Assistance Program in the United States, could widen their scope by increasing the involvement of nutritional educators. However, to target the lower-middle income segment, which is not beneficiary of food stamps, a national campaign to increase the awareness on food waste, preferably involving the private sector as well, would be necessary.

Household food waste remains under-researched in the Brazilian context and the mitigation of consumer food waste is not yet a national priority as perceived, for instance, in the United Kingdom, where the Waste \& Resources Action Programme (Wrap) has acquired good results -1.1 million tonne reduction in household food and drink waste between 2007 and 2012 since the launching of the 'Love Food Hate Waste' campaign (Wrap, 2014). Brazil has established, in 2010, a National Plan for Solid Waste, and more recently a National Plan of Food 
and Nutrition Security under the responsibility of the Ministry of Social Development. However, emphasis is on increasing the access to food in the base of the pyramid, and nutritional education efforts are missing.

Partnerships could be developed with government agencies to amplify the scope of current projects, such as 'Mesa Brasil', a national program led by the Brazilian Social Service of Commerce. Moreover, the current network of 67 food pantries linked to the Ministry of Social Development, in Brazil, could be incremented to operate as nutrition education centers. These efforts could lead to a national plan of smarter food choices, which could also positively impact the consumption of healthier food products.

\section{References}

Aggidis, G., Arbon, I., Brown, C., Clarke, C., Earp, J., Fox, T., Greenway, D., Smith, A., Stannard, B., Warriner, D., Whatley, S., \& Williams, D. (2013) Global food: waste not, want not. [IMECHE document]. London: Institution of Mechanical Engineers, $36 \mathrm{p}$. [Online] [WWW document]. URL http://www.imeche.org/docs/ default-source/news/Global_Food_Waste_Not_Want_Not.pdf (accessed on 14 November 2013).

Beretta, C., Stoessel, F., Baier, U., \& Hellweg, S. (2013) Quantifying food losses and the potential for reduction in Switzerland. Waste Management, 33, 764-773.

Blair, D. \& Sobal, J. (2006) Luxus consumption: wasting food resources through overeating, Agriculture and Human Values, 23, 63-74.

Bolaane, B. \& Ali, M. (2004) Sampling household waste at source: lessons learnt in Gaborone. Waste management \& Research, 22, 142-148.

Bowen, G.A. (2008) Naturalistic inquiry and the saturation concept: a research note. Qualitative Research, 8, 137-152.

Buchner, B., Fischler, C., Reilly, J., Riccardi, G., Ricordi, C., \& Veronesi, U. (2012) Food waste: causes, impacts and proposals. [Barilla center for food and nutrition document]. Codice Edizioni, Parma, Italy.

Buzby, J. (2014) Overview of Food Loss in the United States. The Last Food Mile Conference. Philadelphia, December 8-9. [Online] [WWW document]. URL http://repository.upenn.edu/thelastfoodmile/sessions/ session/34 (accessed on 28 January 2015).

Carvalho, D. (2009) Fome de desperdício de alimentos [Hunger of food waste]. Desafios do Desenvolvimento, IPEA journal, 6. [Online] [WWW document]. URL http://www.ipea.gov.br/desafios/index. php?option=com_content\&id=1256:reportagens-materias\&Itemid=39 (accessed on 18 August 2013).

Cascudo, C. (1968) História da alimentação no Brasil [The history of food in Brazil], Vol. 2, coleção Brasiliana. Companhia Editora Nacional, São Paulo, Brazil.

Chandon, P. \& Wansink, B. (2002) When are stockpiled products consumed faster? a convenience-salience framework of postpurchase consumption incidence and quantity. Journal of Marketing Research, 39, 321-335.

Cox, J. \& Downing, P. (2007) Food Behaviour Consumer Research: Quantitative Phase. Wrap, Banbury UK. [Online] [WWW document]. URL http://www.wrap.org.uk/downloads/Food_behaviour_consumer_ research_quantitative_jun_2007.0a80ed7d.6393.pdf (accessed on 15 September 2013).

DaMatta, R. (1984) O que faz do Brasil, Brasil? [What makes Brazil, Brazil?]. Editora Rocco, Rio de Janeiro, Brazil.

Desjeux, D. (2006) La consommation [The consumption]. Presses Universitaires de France, Paris, France.

Desjeux, D., Suarez, M. \& Campos, R. (2014) The itinerary method: a methodological contribution from social sciences to consumer research in management. Revista Brasileira de Marketing, 13, 74-83.
Evans, D. (2011) Blaming the consumer-once again: the social and material contexts of everyday food waste practices in some English households. Critical Public Health, 21, 429-440.

Evans, D. (2012) Binning, gifting and recovery: the conduits of disposal in household food consumption. Environment and Planning D: Society and Space, 30, 1123-1137.

Evans, D.; Campbell, H. \& Murcott, A. (2013) A brief pre-history of food waste and the social sciences. The Sociological Review, 60, 5-26.

Fajans, J. (2012) Brazilian Food: Race, Class and Identity in Regional Cuisines. Berg Publishers, New York, NY, USA.

FAO. (2013a) Urgent collaboration required on food wastage. Food and Agriculture Organization for the United Nations, Rome. [Online] [WWW document]. URL http://www.fao.org/news/story/en/item/ 202914/icode/ (accessed on 1 July 2014).

FAO. (2013b) The State for Food and Agriculture: Food Systems for Better Nutrition. Food and Agriculture Organization for the United Nations, Rome, Italy.

FAO. (2013c) Food Wastage Footprint: Impacts on Natural Resources. Food and Agriculture Organization for the United Nations, Rome, Italy.

FAO. (2014). Food losses and waste in the Latin America and the Caribbean. Food and Agriculture Organization for the United Nations, Rome. [Online] [WWW document]. URL http://www.fao.org/3/ai3942e.pdf/(accessed on 20 January 2015).

Freyre, G. (2002) Casa-grande \& Senzala [The masters and the slaves]. 46th edn. Editora Record, Rio de Janeiro, Brazil. (First edition from 1933).

Ganglbauer, E., Fitzpatrick, G. \& Comber, R. (2013) Negotiating food waste: using a practice lens to inform design. ACM Transactions on Computer-Human Interaction, 20, 11-25.

Godfray, C. J., Crute, I.R., Haddad, L., Lawrence, D., Muir, J.F., Nisbett, N., Pretty, J., Robinson, S., Toulmin, C., \& Whiteley, R. (2010) The future of the global food system. Philosophical Transactions of the Royal Society, 365, 2769-2777.

Graham-Howe, E. (2013) Carbon foodprint. University of Sussex's psychology research blog. [Online] [WWW document]. URL http:// splash.sussex.ac.uk/blog/for/psychresearch/by/tag/phd (accessed on 25 November 2013).

Graham-Howe, E., Jessop, D.C., \& Sparks, P. (2014) Identifying motivations and barriers to minimising household food waste. Resources, Conservation and Recycling, 84, 15-23.

Gustavsson, J., Cederberg, C. \& Sonesson, U. (2011) Global Food Losses and Food Waste: Extent, Causes and Prevention. Food and Agriculture Organization of the United Nations, Rome, Italy.

Harrison, G.G., Rathje, W.L. \& Hughes, W.W. (1975) Food waste behavior in an urban population. Journal of Nutrition education, 7, 13-16.

IBGE. (2012) Síntese de indicadores sociais: uma análise das condições de vida da população brasileira [Social indicators synthesis: analysis of the Brazilian population life conditions]. Estudo e Pesquisas, $n .29$. Instituto Brasileiro de Geografia e Estatística, Rio de Janeiro, RJ. [Online] [WWW document]. URL http://ftp://ftp.ibge.gov.br/Indicadores_Sociais/Sintese_de_Indicadores_Sociais_2012/SIS_2012.pdf (accessed on 12 September 2013).

IBGE. (2014). Pesquisa Suplementar de Segurança Alimentar [Supplementary Research on Food Security]. Instituto Brasileiro de Geografia e Estatística, Rio de Janeiro, RJ. [Online] [WWW document]. URL http://ftp://ftp.ibge.gov.br/Indicadores_Sociais/Sintese_de_Indicadores_Sociais_2012/SIS_2012.pdf (accessed on 27 January 2015).

Kantor, L.S., Lipton, K., Manchester, A. \& Oliveira, V. (1997) Estimating and addressing American food loss. Food Review, 20, 2-12.

Koivupuro, H-K., Hartikainen, H., Silvennoinen, K., Katajajuuri, J-M., Heikintalo, N., Reinikainen, A. \& Jalkanen, L. (2012) Influence of socio-demographical, behavioural and attitudinal factors on the amount of avoidable food waste generated in Finnish households. International Journal of Consumer Studies, 36, 183-191. 
Leal Filho, W. \& Kovaleva, M. (2015) Food Waste and Sustainable Food Waste Management in the Baltic Sea Region. Springer, Hamburg, Germany.

Milne, R. (2013) Arbiters of waste: date labels, the consumer and knowing good, safe food. The Sociological Review, 60, 84-101.

O'Donnell, T. (2014) Reducing household food waste: food to good to waste program. The Last Food Mile Conference. Philadelphia, December 8-9. [Online] [WWW document]. URL http://repository. upenn.edu/thelastfoodmile/sessions/session/23 (accessed 29 January 2015).

Palatnik, R. R. et al. (2014) Greening Household Behaviour and Waste, OECD Environment Working Papers, No. 76, OECD Publishing. URL http://dx.doi.org/10.1787/5jxrclmxnfr8-en

Parfitt, J., Barthel, M. \& Macnaughton, S. (2010) Food waste within food supply chains: quantification and potential for change to 2050. Philosophical Transactions of the Royal Society Biological Sciences $\mathbf{3 6 5}$, 3065-3081.

Plumb, A. \& Downing, P. (2013) Consumer Attitudes to Food Waste and Food Packaging. Waste \& resources action programme, Barbury, UK.

Pressinott, F. (2013) Desperdício de alimento gera perda de US\$750 bilhões por ano, diz FAO [Food waste generates lost of US $\$ 750$ bi per year, says FAO] 11 set. Valor Econômico. [Online] [WWW document]. URL http://www.valor.com.br/imprimir/noticia/3266358/agro (accessed on 15 September 2013).

Quested, T. \& Johnson, H. (2009) Household Food and Drink Waste in the UK. Waste \& resources action programme, Banbury, UK.

Rial, C.S.M. (2005) Brasil: primeiros escritos sobre comida e identidade [Brazil: first manuscripts about food and identity]. In Antropologia e nutrição: um diálogo possível, (ed. by A.M. Canesqui, \& R.W.D. Garcia), pp. 87-100. Editora Fiocruz, Rio de Janeiro, Brazil.

Schneider, F. (2008) Wasting food-an insistent behavior. Urban issues \& solutions. Waste, the social context. May 11-15, Edmonton, Canada.

Sheth, J.N., Gardner, D.M., \& Garrett, D.E. (1988) Marketing theory: evolution and evaluation. Wiley, New York.

Soares, A.G. (2009) Perdas pós-colheita de frutas e hortaliças [Post-harvest losses of fruits and greenery]. Fórum Agronegócios da UNICAMP_Qualidade e Segurança de Alimentos. [Online] [WWW document]. URL http://www.unicamp.br/nepa/downloads/ PerdasPos

ColheitasFrutaseHortalicas.pdf (accessed on 12 February 2014).

Stefan, V., van Herpen, E., Tudoran, A.A. \& Lähteenmäki, L. (2013) Avoiding food waste by Romanian consumers: The importance of planning and shopping routines. Food Quality and Preference, 28, $375-381$.
Stern, P.N. (2007) On solid ground: essential properties for growing grounded theory. In: The Sage Handbook of Grounded Theory (ed. by Bryant, Antony; Charmaz, Kathy), pp. 114-127. Sage publications, London, UK.

Stuart, T. (2009) Waste: Uncovering the Global Food Scandal. W.W. Norton \& Company, New York.

Terpstra, M.J., Steenbekkers, L.P.A., Maertelaere, N.C.M. \& Nijhuis, S. (2005) Food storage and disposal: consumer practices and knowledge. British Food Journal, 107, 526-533.

UNDP. (2013) O índice de desenvolvimento humano municipal brasileiro. [The Brazilian Human Development Index by Municipalities] United Nations Development Programme, Brasília, DF. [Online] [WWW document]. URL http://www.pnud.org.br/arquivos/idhmbrasileiro-atlas-2013.pdf (accessed on 5 August 2014).

UNDP. (2014) Sustaining Human Progress: Reducing Vulnerabilities and Building Resilience. Human Development Report 2014. United Nations Development Programme, New York. [Online] [WWW document]. URL http://hdr.undp.org/sites/default/files/hdr14report-en-1.pdf (accessed on 15 August 2014).

Wansink, B. (2001) Abandoned products and consumer waste: how did that get into the pantry? Choices, October, 46.

Wansink, B., Brasel, S. \& Amjad, S. (2000) The mystery of the cabinet castaway: why we buy products we never use. Journal of Family and Consumer Science, 92, 104-108.

Wansink, B. \& Deshpandé, R. (1994) Out of sight, out of mind: the impact of household stockpiling on usage rates. Marketing Letters, 5 , 91-100.

Wansink, B., van Ittersum, K. \& Payne, C.R. (2014) Larger bowl size increases the amount of cereal children request, consume, and waste. Journal of Pediatrics, 164, 323-326.

Wansink, B. \& van Ittersum, K. (2014) Portion size me: plate size can decrease serving size, intake, and food waste. Journal of Experimental Psychology: Applied, 19, 320-332.

Williams, H., Wikström, F., Otterbring, T., Löfgren, M. \& Gustafsson, A. (2012) Reasons for household food waste with special attention to packaging, Journal of Cleaner Production, 24, 141-148.

World Bank. (2013) World development indicators. The World Bank. [Online] [WWW document]. URL http://data.worldbank.org/country/ brazil (accessed on 27 September 2013).

Wrap. (2014) Household food waste prevention case study: West London Waste Authority in partnership with Recycle for London. London: Waste \& Resources Action Programme (Wrap). [Online] [WWW document]. URL http://www.pnud.org.br/arquivos/idhm-brasileiroatlas-2013.pdf (accessed on 30 March 2015). 


\section{Appendix}

Sample of photos taken by the authors for the study during home-tours.
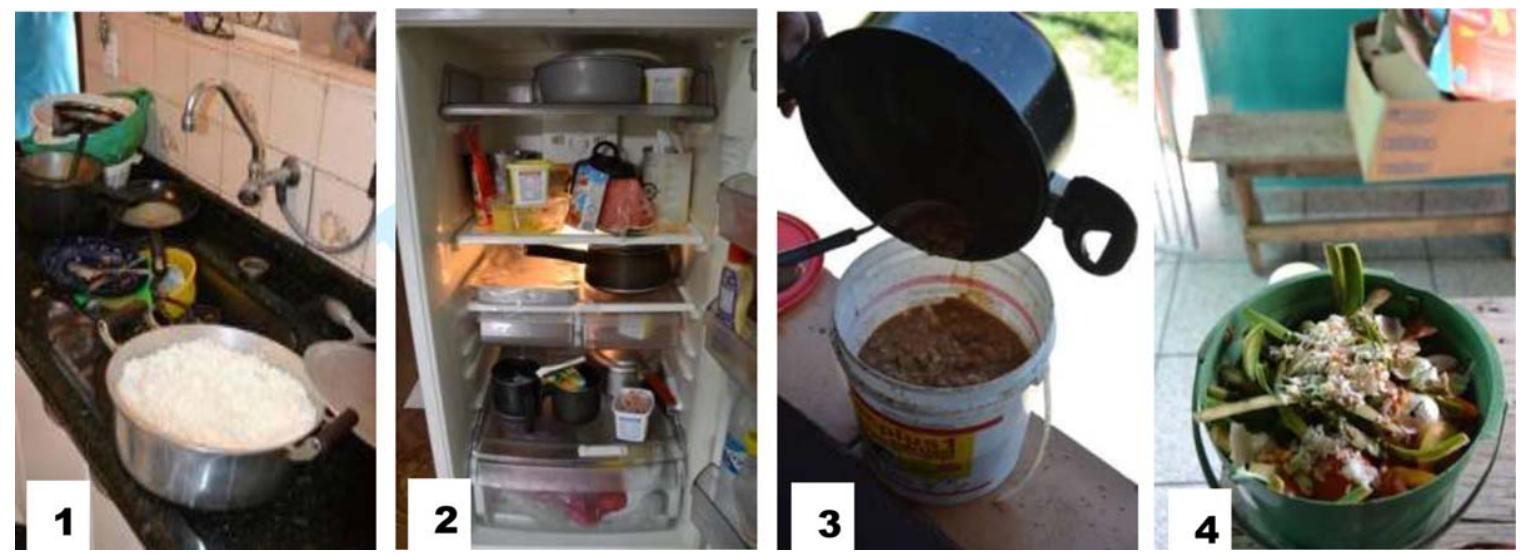

1. Over-preparation: pan of rice as leftover; 2. Food storage; 3 and 4. Food disposal. [Color figure can be viewed in the online issue, which is available at wileyonlinelibrary.com.]
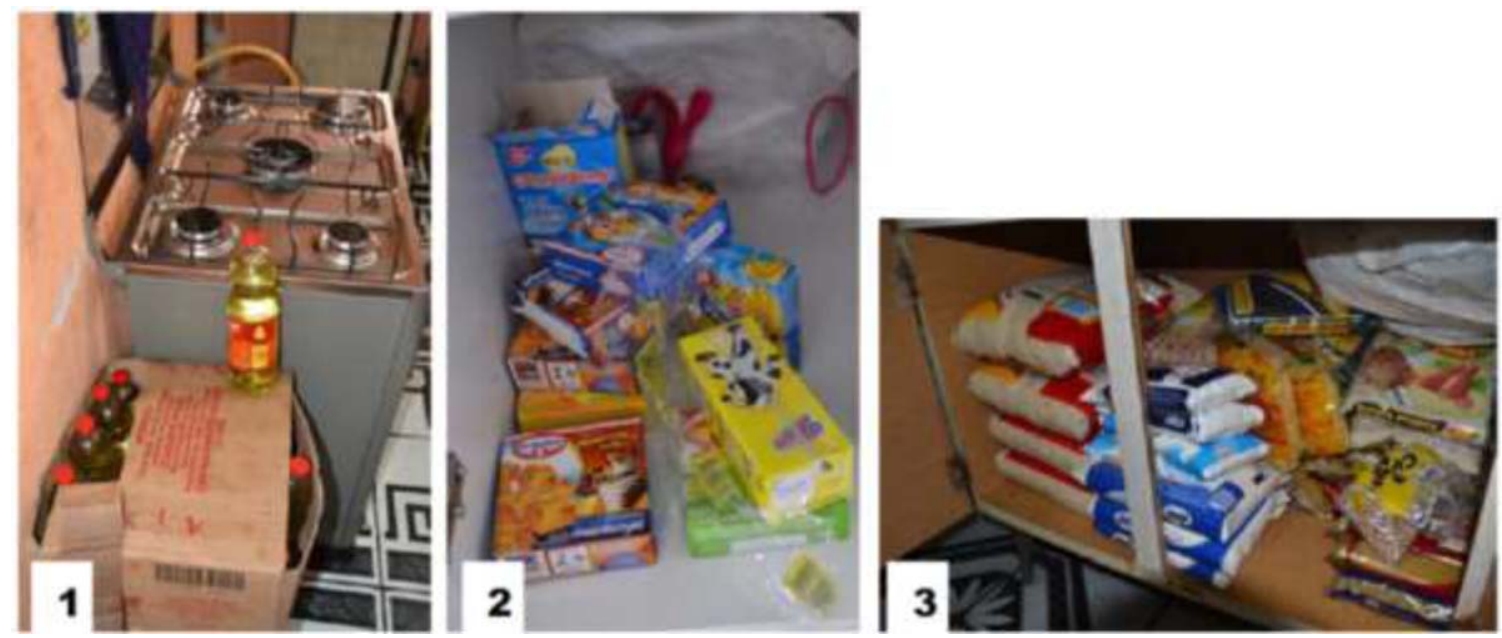

1. Bulk buying leading to ample storage; 2. Expired products; 3 . Abundant stock. [Color figure can be viewed in the online issue, which is available at wileyonlinelibrary.com.] 